\title{
PERCEPTIONS OF COLOSTOMY PATIENTS ABOUT NURSING CARE IN ONCOLOGY INPATIENT UNITS
}

\author{
Cláudia Bruna Perin ${ }^{1, *}$ (D), Andréia Machado Cardoso² (D), Alessandra Yasmin \\ Hoffmann² (D), Vanessa Zancanaro² (D), Vanessa Manfrin' (D)
}

\begin{abstract}
Objective: To analyze the perceptions of colorectal cancer patients using colostomy on the nursing care of the oncology inpatient units of a hospital in western Santa Catarina. Methods: Descriptive-exploratory study of qualitative approach carried out in the oncology inpatient units of the Hospital Regional do Oeste, in the period from January to August 2020, through a questionnaire containing sociodemographic data and semi-structured interview, applied to 20 patients with colorectal cancer using colostomy. The data were analyzed using Laurence Bardin's Content Analysis. Results: The results indicated a prevalence of colostomy male patients, with a mean age of 60.25 years, married, retired, and with incomplete elementary education. From the qualitative analysis of the interviews emerged the category: patients' perceptions of nursing care, which was subdivided into: nursing care with the bag and the stoma and nursing care during hospitalization. Conclusion: At the end of the survey, it is concluded that the colostomy patients perceive that the nursing staff performs the essential care of the bag and the stoma, including its exchange and hygiene during hospitalization, meeting the patients' needs. In addition, they provide important guidance on the use of the devices, promoting health education.
\end{abstract}

DESCRIPTORS: Colostomy. Nursing care. Colorectal neoplasia. Oncology. Qualitative research. Enterostomal therapy.

\section{PERCEPÇÕES DE PACIENTES COLOSTOMIZADOS SOBRE OS CUIDADOS DE ENFERMAGEM DAS UNIDADES DE INTERNAÇÃO EM ONCOLOGIA}

\section{RESUMO}

Objetivo: Analisar as percepções dos pacientes com câncer colorretal em uso de colostomia sobre os cuidados de enfermagem das unidades de internação em oncologia de um hospital do oeste de Santa Catarina. Métodos: Estudo descritivo-exploratório de abordagem qualitativa realizado nas unidades de internação em oncologia do Hospital Regional do Oeste, no período de janeiro a agosto de 2020, por meio de um questionário contendo dados sociodemográficos e entrevista semiestruturada, aplicado a 20 pacientes com câncer colorretal em uso de colostomia. Os dados foram analisados por meio da Análise de Conteúdo de Laurence Bardin. Resultados: Os resultados apontaram prevalência de colostomizados do sexo masculino, com idade média de 60,25 anos, casados, aposentados e com ensino fundamental incompleto. A partir da análise qualitativa das entrevistas surgiu a categoria: percepções dos pacientes sobre os cuidados de enfermagem, a qual foi subdividida em: cuidados de enfermagem com a bolsa e a estomia e cuidados de enfermagem na internação. Conclusão: Ao término da pesquisa, conclui-se que os colostomizados percebem que a equipe de enfermagem realiza os cuidados essenciais

\footnotetext{
1. Associação Hospitalar Lenoir Vargas Ferreira - Chapecó (SC), Brazil.

2. Programa de Pós-Graduação em Ciências Biomédicas, Universidade Federal da Fronteira Sul - Chapecó (SC), Brazil. *Correspondence author: claudia_perin@yahoo.com.br
} Section Editor: Isabel Cristina R V Santos Received: Mar. 2021, 02 | Accepted: May 2021, 06 How to cite: Perin CB; Cardoso AM; Hoffmann AY; Zancanaro V; Manfrin V. Perceptions of colostomy patients about nursing care in oncology inpatient units. ESTIMA, Braz. J. Enterostomal Ther., 2021, 19: e1521. https://doi.org/10.30886/estima.v19.1025_IN 
à bolsa e à estomia, incluindo sua troca e higiene durante a internação, atendendo às necessidades dos pacientes. Além disso, fornecem orientações importantes sobre o uso dos dispositivos, promovendo educação em saúde.

DESCRITORES: Colostomia. Cuidados de enfermagem. Neoplasias colorretais. Oncologia. Pesquisa qualitativa. Estomaterapia.

\section{PERCEPCIONES DE PACIENTES COLOSTOMIZADOS SOBRE EL CUIDADO DE ENFERMERÍA DE LAS UNIDADES DE ONCOLOGÍA}

\section{RESUMEN}

Objetivo: Analizar las percepciones de los pacientes con cáncer colonrectal mediante colostomía sobre la atención de enfermería de las unidades de internación de oncología de un hospital del oeste de Santa Catarina. Métodos: Estudio descriptivo-exploratorio con abordaje cualitativo, realizado en las unidades de internación de oncología del Hospital Regional do Oeste, de enero a agosto de 2020, mediante un cuestionario que contiene datos sociodemográficos y entrevista semiestructurada, aplicado a veinte pacientes con cáncer colonrectal mediante colostomía. Los datos se analizaron mediante el análisis de contenido de Laurence Bardin. Resultados: Los resultados mostraron una prevalencia de pacientes colostomizados del sexo masculino, con una edad promedio de 60,25 años, casados, jubilados y con educación primaria incompleta. Del análisis cualitativo de las entrevistas surgió la categoría: Percepciones de los pacientes sobre los cuidados de enfermería, la cual se subdividió en: Cuidados de enfermería con bolsa y ostomía y Cuidados de enfermería durante la hospitalización. Conclusión: Al final de la investigación, se concluye que los pacientes colostomizados perciben que el equipo de enfermería realiza los cuidados esenciales de la bolsa y la ostomía, incluido su intercambio e higiene y también, durante la hospitalización, la satisfacción de las necesidades de los pacientes. Además, brindan una guía importante sobre el uso de dispositivos, promoviendo la educación para la salud.

DESCRIPTORES: Colostomía. Cuidado de enfermera. Neoplasias colonrectales. Oncología. Investigación cualitativa. Estomaterapia.

\section{INTRODUCTION}

Bowel cancer is that which starts in the colon, rectum, or anus, also known as colorectal cancer. It is treatable and, in most cases, when detected early, curable. Most of these tumors originate from polyps, which are benign lesions inside the intestine ${ }^{1}$.

For Brazil, an estimated 20,540 cases of colorectal cancer in men and 20,470 in women are expected for each year in the triennium 2020-2022. This corresponds to an estimated risk of 19.64 new cases per 100,000 men and 19.03 per 100,000 women $^{2}$.

Considering the regions of Brazil, with the exception of non-melanoma skin cancer, colorectal cancer ranks second in men in the Southeast and Midwest regions, third in the South, and fourth in the North and Northeast. For women it is the second most frequent in the South and Southeast Regions and the third most incident in the North, Northeast, and Midwest Regions².

A colostomy is created when part of the large intestine is removed and another exteriorized. This results in a change in the body for the elimination of feces. When the colostomy is temporary, it can be reversed and bowel activity resumes its normal function. However, when the end portion of the colon or rectum becomes compromised, a permanent ostomy may be necessary ${ }^{3}$.

The individual living with cancer suffers daily the contradictory process between health and disease and needs to be the protagonist of this phase, creating life projects that express quality of life and contain within themselves the complexity that needs to be considered in the health-disease phenomenon ${ }^{4}$. Thus, as the representation of colorectal cancer patients about the quality of life after intestinal ostomy is known, it is possible that there will be improvements in the assistance, 
as well as the awareness of the multidisciplinary health team, to understand the common sense, providing a rehabilitation and quality of life to these individuals 5 .

Systematic nursing intervention in enterostomal therapy, ranging from the preoperative period, continuing in the postoperative period and follow-up allows for the creation of adaptive strategies and new knowledge in the management of care for the ostomy, favoring psychosocial adaptation ${ }^{6}$. In addition, the need for the use of materials and other equipment for the care of the stoma and the skin is considered something new, different and so the provision of guidance is indispensable ${ }^{7}$.

Throughout the process, the colostomy patient experiences significant changes in his or her life, which affect not only the physiological, but also the psychological, physical, emotional, spiritual, and sexual aspects, which have repercussions on the quality of life. Thus, it needs attention in all its aspects during the rehabilitation process. Thus, nursing is very important in this phase, helping the individual and family members to choose the best equipment, informing them about the diets, and clarifying doubts related to the ostomy ${ }^{5}$.

Finally, the nurse acts as a mediator and facilitator of care, which enables the development of skills for care and the welcoming of doubts, fears, and anxieties presented by these people and their families. Thus, the communication process enables effective exchanges between nurse and client, which provides the minimization of difficulties arising from the ostomy ${ }^{8}$.

The research is justified because it is known how important nursing is in the lives of people with ostomies, and understanding how patients perceive nursing care allows these professionals to rethink and create strategies that provide better quality of life for these individuals in all its dimensions. Moreover, it is worth considering that even with other studies related to the theme, worldwide, in the research hospital there are no studies on the subject, and in view of the importance of the issue, the need to develop this research is justified. Thus, the guiding question of the study was: "what is the perception of patients with colorectal cancer using a colostomy about the nursing care received in the oncology inpatient units of a hospital in western Santa Catarina?".

\section{OBJECTIVE}

To analyze the perceptions of patients with colorectal cancer using a colostomy on nursing care in the oncology inpatient units of a hospital in western Santa Catarina.

\section{METHODS}

This is a descriptive-exploratory study with a qualitative approach. The field of study was composed of the oncology inpatient units (Oncology I and II) of the Hospital Regional do Oeste, located in Chapecó - Santa Catarina. The institution has 319 beds, 275 of which are registered in the Cadastro Nacional de Estabelecimentos de Saúde (CNES)9.

Currently, based on information from the hospital in question, it is estimated that approximately 40 colorectal cancer patients using a colostomy are admitted for treatment in the oncology inpatient units per semester.

The sample was defined by saturation. Sample closure by theoretical saturation is operationally defined as the suspension of the inclusion of new participants when the data obtained begins to present, in the evaluation of the researcher, a certain redundancy or repetition, not being considered relevant to persist in data collection ${ }^{10}$. Thus, the sample was composed of 20 patients with colorectal cancer using a colostomy, admitted to the oncology inpatient units of the Hospital Regional do Oeste.

Were included: patients with colorectal cancer using a colostomy, aged between 25 and 75 years, admitted for treatment in the oncology inpatient units (Oncology I and II) of the Hospital Regional do Oeste, during the period established for data collection. Patients with cancer other than colorectal cancer or who do not have a colostomy were excluded.

For data collection, which occurred in the period from January to August 2020, a research instrument was employed consisting of a questionnaire identifying the patient, containing sociodemographic data and a semi-structured interview about the patient's perceptions of nursing care. 
Participants were chosen based on disease staging and age, aiming for similarity in these criteria. For the approach to the patients, the researcher would go to the bed where they were and explain about the research, its objectives, risks and benefits. If they agreed to participate, they were invited to a reserved room, located in the oncology inpatient units, to facilitate data collection, so that there would be no interruptions. All those approached were able to move around without risk, and the room used for the interviews was defined on the day with the sector nurse, and most of the time the alternative therapy room was used.

After reading and filling out the Informed Consent Form and the Consent Form for the use of image and/or voice, the interviews were started. These were recorded (audio) to avoid the loss of speech details and had an average duration of $15 \mathrm{~min}$.

Laurence Bardin's method was used to analyze the data, which organizes the phases of content analysis into three main chronological orders: pre-analysis; exploration of the material; and treatment of the results, inference and interpretation ${ }^{11}$.

In the first phase, after collecting data through a semi-structured interview, the transcription of the speeches began. At this moment, it was possible to listen to the patients' speeches several times, being impregnated with them, which allowed the creation of notes to the research objectives and a brief notion of the perception of these individuals about the nursing care received in oncology inpatient units.

In the second phase a table was created divided into themes about the subject, which emerged from the first phase of the analysis. After that, the sub-themes were highlighted by various colors, i.e., what each patient reported about the themes that emerged, and then these statements were cut and pasted in the corresponding place in the table.

In the last phase, the clippings were read and then interpreted and described by the researchers. In addition, several categories emerged after the analysis of the results, but those that met the research objectives were chosen, and after the organization and description of the speeches, the discussion process began.

Regarding the risks of the research, which could be on the physical, moral, intellectual, social or cultural dimension. Given this situation, data collection would only continue if the participants were emotionally able to continue, otherwise the interview would be discarded or rescheduled for a later time.

Considering the possibility of risks that could be aroused by the interview, the assistance team of the Hospital Regional do Oeste, especially psychology, would be requested to provide assistance to the patient if necessary, according to the agreement previously established between the research supervisor and the institution's staff. In addition, the necessary referrals would be made by the public health network, through the Unified Health System. If it was necessary to provide support with medication or medical care, the support would be provided by the researcher, as long as these medications and medical care were effective for the psychological and physiological damage triggered by the interview.

The benefits obtained through the production of information consisted of: giving greater visibility to the theme, contributing to the improvement of nursing care to patients with colorectal cancer using a colostomy. They also provided subsidies for the construction of knowledge in the Nursing and Health Area, as well as for new research to be developed on this theme.

Aiming to meet the ethical requirements, the research project was first approved by the Research Ethics Committee of the Universidade Comunitária da Região de Chapecó (UNOCHAPECÓ), being registered through Plataforma Brasil under Opinion number 3.720.115, CAAE: 24646619.5.0000.0116. The research was initiated after authorization from the institution where the study was developed, through the Declaration of Science and Agreement of the Involved Institutions.

To ensure confidentiality and anonymity, the research participants were asked to sign the Informed Consent Form (ICF). The document was signed in two copies of equal content, with one remaining with the researchers and the other with the interviewed patients. The data collection material will be stored by the researchers in a place of their exclusive access for a period of five years, and will be destroyed after the established period. The research was committed to the privacy and confidentiality of the data used, preserving the anonymity of the interviewees, who were identified by codenames referring to the letter P for patient, followed by the number of the interview (for example: P1, P2, etc.). 


\section{RESULTS}

A total of 20 patients were interviewed, with a mean age of $60.25 \pm 8.41$ years, with $75 \%$ being male and $25 \%$ female. Regarding race, the majority (85\%) declared themselves to be white. The prevalent age group was the elderly, with $55 \%$ of the sample studied. As to marital status, 75\% were married. The number of children varied from 1 to $3(80 \%)$ and from 4 to 8 (20\%). Regarding the municipality of residence, $25 \%$ live in Chapecó and $75 \%$ in neighboring cities. Of those interviewed, $95 \%$ own their homes and $90 \%$ live with relatives. Regarding work occupation, the majority (55\%) are retired. The education level most cited was incomplete elementary school (50\%). Regarding the monthly income of the family, $50 \%$ receive from less than 1 minimum wage up to 3 minimum wages.

Regarding colorectal cancer, $80 \%$ of the interviewees have had the disease from 1 month to 2 years, and 20\% over 2 years. The time of experience with the colostomy was represented by $85 \%$ of the interviewees who have had it from 20 days to 2 years. Most patients are in stage IV of the disease (70\%), and regarding the number of hospitalizations, $40 \%$ have been hospitalized from 1 to 10 times, $40 \%$ from 11 to 20 times, 15\% from 21 to 40 times, and 5\% more than 40 times.

The qualitative data analysis allowed the construction of the following category: patients' perceptions of nursing care. For didactic purposes, this category was subdivided into two subcategories: nursing care of the bag and the stoma and nursing care at hospitalization.

\section{Patients' perceptions of nursing care}

Nursing care for people with ostomies requires specific knowledge by the nurse. In addition, care should be in full, considering the client's needs at all stages of the process, from preoperative to rehabilitation ${ }^{12}$. Thus, it is necessary to put into practice humanized nursing care based on scientific evidence, encompassing all the people involved in the process, ensuring the success of the treatment ${ }^{13}$.

From the analysis of the interviewees' speeches, two subcategories about nursing care emerged, which are described below.

\section{Nursing care of the bag and the stoma}

The patients interviewed reported that the nurses and nursing staff performed care of the bag and the stoma, including hygiene, using water or even saline for cleaning, gauzes, forceps, and products for maintaining the ostomy. They also performed the exchange of the bag, including in situations where accidents occurred.

Below are clippings of the patients' main statements on the subject:

[...] I was hospitalized there in the beginning, that they placed the colostomy [...], they always came [the nursing], they treated me really well, they always removed the excess of things, sanitized the bag, changed it when needed [...]. Here, before the beginning it was always them who did [the exchange of the bag] [...], their cleaning, they came with a little tray, the gauzes there in general, clean, take, clean, wash, wipe [...]. [They used] water, I think it was water or, I think it was even serum, they sanitized it, cleaned it, dried it well, then they put that other bag [...], they just cut the size [...], put it on, adapted it back, everything exactly right, even in chemotherapies it happened to burst [...], then they changed it for me [...]. (P20)

[...] I asked for help [...] she [nurse] went there in a flash and changed [...]. I had already gone to the bathroom, and then I cleaned it with water in a little bottle [...], I opened the toilet, but there to wash it, brushing it, and then I got the washcloths, and then I said (to her) it is ready, now help me, and then I went to the bed [...], they changed [...], she [used] the serum to wash it, and then I have some products [...]. Until these days the nurse asked how I was [...], then I said: it is normal, if it did not come [the intestine out], mine did not [...]. (P18) 
As most of the interviewees reported, the nursing staff taught hygiene and changing the bag, and investigated colostomy complications, whether the colostomy was working properly, and whether the patient needed help changing the bag.

They helped a lot, they taught how to do [the hygiene and exchange of the bag] and then we adapted [...]. They changed [the bag] [...], it was changed four times already [...], it is all the care, with all the cleaning, done with asepsis, with gauze, with (some) extension scissors for cleaning [...], masks, all the care, with goggles too, because besides everything, besides the smell, it can expel it, right? [...] (P12)

About the colostomy too, they just ask, right? If it does not, if the skin is not irritated, if it is working well, that's it, right? (P13)

Finally, some reports showed that the nurses and their staff did not perform the exchange of the bag, mainly because the patient already knows how to do it by himself.

At first they always ask if I need help, if I can change, if I need them to change [...]. None changed, because then there was never any need, when I came, one day I would come and go back, there was no need and when I was a resident I never did either, then I already knew how to use, the times I needed, I did it myself [...]. (P10)

\section{Nursing care during hospitalization}

As for inpatient care, the interviewees commented on the care provided by the nursing staff, among which they listed: the affection, attention, concern for the patient, and the care received. From orientations, answering questions, solving problems, performing a physical exam, and even requesting care from the multiprofessional team.

Below are clippings of the patients' main speeches on the subject:

Every time you call them they come, they give you a lot of attention [...], if you need an orientation, they come to explain, you ask for something, everybody, then they also called the nutritionist, the physiotherapist [...]. If they have to come ten times in your room, they do [...]. (P19)

[...] They have a great affection, some care like that, we call them they come, questions about changing medicine, like that [...], but in the emergency I call them. (P5)

[...] Then they would come to measure the pressure, because it was a pain in the chest like that, like a shortness of breath and such, and then they would see that it was nothing, because the heart is beating normally, the pressure is normal, everything is normal, and suddenly it would pass [...]. (P8)

\section{DISCUSSION}

Nursing professionals emerge as supportive figures in the transition experienced by people with stomata, with the nurse being the central figure in this process ${ }^{14}$. Nursing care for these people is important because it allows the development of self-care, insertion into social life, prevention of complications related to the ostomy and acceptance of the disease ${ }^{15}$.

It is perceived that this assistance must be provided in all operative phases, enabling the adaptation of the person with the ostomy to the new lifestyle, besides providing the orientations related to the care with the stoma and the collecting bag, such as hygiene, acquisition of products, feeding, and actions to avoid complications ${ }^{15}$.

In the study by Paczek et $\mathrm{al}^{16}$, the main reasons people with stoma sought nursing care were evaluated. Among them are: the exchange of the bag, annual evaluation, first consultation, low durability of the bag, dermatitis, cauterization, orientation, and irrigation. These actions are of great relevance, since they stimulate self-care and help improve the user's quality of life. 
This information is in line with the present research, as the nursing staff of the place studied performs the hygiene and exchange of the bag and teaches the user this activity, observing, also, if there are no complications related to the ostomy. Considering the fragility of the person with ostomy, after being submitted to the colostomy procedure, nursing becomes essential in the care of this client in all operative periods, and it is this interaction that will allow the development of self-care.

It is paramount that there is monitoring by an experienced nurse with knowledge of devices for ostomies, considering that the type of device used can also be a risk factor for the emergence of peristomal complications. Related to this is the fact that proper preoperative marking allows better adaptation to the devices, just as different types of stomata may require different types of devices ${ }^{17}$.

In a research conducted by Ribeiro and Andrade ${ }^{18}$, it was evidenced that maintaining the cleanliness of the bag provides greater well-being to the patient. Thus, cleaning the peristomal skin, followed by a proper exchange is fundamental for health promotion, since it avoids complications. Furthermore, hygiene care is intrinsic to the science of nursing ${ }^{19}$.

Considering the speeches of the interviewed patients, it can be seen that the nurses and the nursing team are able to provide colostomy-oriented care. However, this care still presents some weaknesses, especially in the reports in which these professionals did not perform this hygiene and exchange. Although many patients already know how to perform the technique, it is important to observe if it is being done correctly, if there are doubts, if the products used are the most adequate, if there are no complications in the colostomy, if the patient is receiving the materials for hygiene and exchange at home, and mainly, if the patient's socioeconomic conditions allow for adequate care. In addition, nursing care should go beyond the colostomy and extend to look at the human being as a whole, considering, especially, how he feels when facing this situation and how he is adapting to it.

In the study by Anacleto, Cecchetto and Riege ${ }^{20}$ it was possible to identify the importance of humanized care and also the factors that influence humanized nursing care, related to the behavior of professionals. Moreover, when these are satisfied with their profession, they work more motivated ${ }^{21}$.

Considering this information, it can be seen that according to the participants of this study, nursing professionals provide humanized care. In this way, they attend to the patients' requests, being concerned with their well-being and effectively performing the actions that are within their competence.

Cancer patients need nursing care as they face many difficulties and side effects related to treatment ${ }^{22}$. In a study by Santana e Silva et $\mathrm{al}^{23}$, the main nursing care for cancer patients found in the articles were: verification of vital signs, pain control, airway clearance, daily dressings, care with probes and drains, and educational actions on self-care. In this study, the main nursing cares mentioned were: verification of vital signs, physical examination, orientation, request for care by the multiprofessional team, problem solving, acting in emergencies, and visits to the rooms.

In caring for colostomy patients, the nurse is important for surgical recovery, teaching self-care, and social readaptation. To this end, it is essential that it uses the Systematization of Nursing Care, promoting individualized, critical, reflective and integral care ${ }^{24}$.

In the research by Peiter et $\mathrm{al}^{21}$, respondents reported their frustrations and realizations regarding the effectiveness of the actions used in cancer patient care. Still, according to the researchers, the ideal care dreamed of by nurses will only be possible through teamwork.

Analyzing the statements of the interviewees of this research, it can be seen that nursing, for the most part, is concerned with providing care considering the life context of people with stoma. Thus, it guides them so that they are not left with doubts, besides involving professionals from other specialties, providing a multidisciplinary service.

Specialized care for cancer patients requires professionals to communicate adequately about the health situation, as well as to discuss the conduct adopted by the team. Thus, nursing care management is considered a strategy for targeted care, and implies the qualification of the assistance provided ${ }^{21}$.

Finally, nursing was described as helpful, supportive, and prudent. Moreover, its members proved to be willing and fulfilled their role, carrying out, whenever necessary, the appropriate care in the hospitalization. But on a day-to-day basis, some weaknesses are perceived, and often the patients' requests go unnoticed, mainly due to the great demand of activities. 


\section{CONCLUSION}

It was possible to identify from this study that colorectal cancer patients using a colostomy perceive that the nursing staff of oncology inpatient units provide colostomy-related care. This care is focused on hygiene, product use, and bag change, as well as management of complications. In addition, it also performs care during hospitalization, which is fundamental for the quality of the treatment.

Despite the relevance of the data found, the research presents limitations, such as the fact that it was developed in only one hospital institution and did not glimpse the educational action of nursing and the preparation for self-care of people with stoma. Its results show how nursing care is provided in the units studied and contribute to learning in the nursing field about the topic, as well as serving as a basis for other studies that address and complement the research in question. Still, they provide nurses with knowledge about the reality of care, and from this, they can improve it, with the intention of improving the quality of life of these individuals.

It is expected that this study may generate reflections in nurses, nursing staff, and managers, so as to enable continuing education activities for health professionals involved in the care of people with colostomy, besides providing subsidies for a humanized care, allowing a better quality of life for these individuals.

\section{AUTHOR'S CONTRIBUTION}

Conceptualization: Perin CB, Cardoso AM, Hoffmann AY, Zancanaro V e Manfrin V; Formal analysis: Perin CB, Hoffmann AY e Zancanaro V; Methodology: Perin CB, Cardoso AM, Hoffmann AY, Zancanaro V e Manfrin V; Investigation: Perin CB; Supervisão: Perin CB e Cardoso AM; Writing - First draft: Perin CB, Hoffmann AY e Zancanaro V; Writing - Review \& Editing: Perin CB; Recursos: Perin CB.

\section{AVAILABILITY OF RESEARCH DATA}

All data were generated or analyzed in the present study.

\section{ACKNOWLEDGMENTS}

To the Associação Hospitalar Lenoir Vargas Ferreira for the support in the development of the research.

\section{REFERENCES}

1. Instituto Nacional de Câncer José Alencar Gomes da Silva (BR). Tipos de Câncer- Câncer de Intestino. Rio de Janeiro: Ministério da Saúde.

2. Instituto Nacional de Câncer José Alencar Gomes da Silva (BR). Estimativa 2020- síntese de resultados e comentários. Rio de Janeiro: Ministério da Saúde; 2020.

3. United Ostomy Associations of America, INC. (US). Colostomy guide; 2017.

4. Costa JM, Finco GM, Souza RLG, Medeiros WCM, Melo MCM. Repercussões biopsicossociais do diagnóstico de câncer colorretal para pacientes oncológicos. Rev SBPH. 2016;19(2):5-23. Available at: http://pepsic.bvsalud.org/pdf/rsbph/v19n2/v19n2a02.pdf

5. Batista RQ, Ramos RS, Bernardes MMR, Barbosa CA, Costa JM. Representação social da qualidade de vida após o estoma intestinal pelo paciente com neoplasia colorretal. Revista Enfermagem Atual. 2018;86(24). https://doi.org/10.31011/reaid2018-v.86-n.24-art.85

6. Souza CF, Santos CB. O cuidado de enfermagem em estomaterapia: desenvolvimento de um programa de intervenção. Enferm Foco 2019;10(5):161-66. Available at: http://revista.cofen.gov.br/index.php/enfermagem/article/view/2314/0

7. Mota MS, Gomes GC, Silva CD, Gomes VLO, Pelzer MT, Barros EJL. Autocuidado: uma estratégia para a qualidade de vida da pessoa com estomia. Investig. enferm. 2015;18(1):63-78. https://doi.org/10.11144/Javeriana.ie18-1.aeqv 
8. Dalmolin A, Girardon-Perlini NM, Coppetti LC, Rossato GC, Gomes JS, Silva ME. Vídeo educativo como recurso para educação em saúde a pessoas com colostomia e familiares. Rev gaúcha enferm. 2016;37(esp.):e69373. https://doi.org/10.1590/19831447.2016.esp.68373

9. Associação Hospitalar Lenoir Vargas Ferreira. Resumo das Atividades [Ano 2018]. 2018. Available at: https://alvf.org.br/wpcontent/uploads/2019/07/resumo-das-atividades-ano-2018-digital.pdf

10. Denzin NK, Lincoln YS, editors. Handbook of qualitative research. Thousand Oaks: Sage Publi- cations; 1994.

11. Bardin L. Análise de conteúdo. Edição Revista Actualizada 70; 2010.

12. Schwalm MT, Ceretta LB, Farias BM, Bonfanti MD, Zimmermann KC, Perfoll R et al. Perfil das pessoas estomizadas atendidas na clínica escola de enfermagem da Universidade do Extremo Sul Catarinense- UNESC. Revista Iniciação Científica. 2013;11(1):97105. Available at: http://periodicos.unesc.net/iniciacaocientifica/article/view/1626/1538\#

13. Ewald F, Danielski K. Cuidado de enfermagem diante do diagnóstico de câncer de mama. RIES. 2013;2(1):58-78. Available at: https://periodicos.uniarp.edu.br/index.php/ries/article/view/100/131

14. Freire DA, Angelim RCM, Souza NR, Brandão BMCM, Torres KMS, Serrano SQ. Autoimagem e autocuidado na vivência de pacientes estomizados: o olhar da enfermagem. REME Rev. Min Enferm. 2017;21:e-1019. https://doi.org/10.5935/14152762.20170029

15. Carvalho BL, Silva ANB, Rios DRS, Lima FES, Santos FKV, Santana FLF et al. Assistência de enfermagem a pacientes com estoma intestinal. REAS/EJCH. 2019;24:e604:01-08. https://doi.org/10.25248/reas.e604.2019

16. Paczek RS, Engelmann Al, Perini GP, Aguiar GPS, Duarte ERM. Perfil de usuários e motivos da consulta de enfermagem em estomaterapia. Rev enferm UFPE on line. 2020;14:e245710. https://doi.org/10.5205/1981-8963.2020.245710

17. Pinto IES, Queirós SMM, Queirós CDR, Silva CRR, Santos CSVB, Brito MAC. Fatores de risco associados ao desenvolvimento de complicações do estoma de eliminação e da pele periestomal. Revista de Enfermagem Referência. 2017;IV(15):155-66. https:// doi.org/10.12707/RIV17071

18. Ribeiro WA, Andrade M. Perspectiva do paciente estomizado intestinal frente a implementação do autocuidado. Revista próuniverSUS. 2020;11(1):06-13. https://doi.org/10.21727/rpu.v11i1.2214

19. Fonseca EF, Martins MMPS, Cardoso MFPT, Ribeiro MIB. Enfermagem de reabilitação nos cuidados de higiene: uma intervenção para autonomia. RIASE online. 2020;6(1):2165-74. Available at: http://revistas.uevora.pt/index.php/saude_envelhecimento/ article/view/429/683

20. Anacleto G, Cecchetto FH, Riegel F. Cuidado de enfermagem humanizado ao paciente oncológico: revisão integrativa. Rev Enferm Contemp. 2020;9(2):246-54. https://doi.org/10.17267/2317-3378rec.V9i2.2737

21. Peiter CC, Caminha MEP, Lanzoni GMM, Erdmann AL. Gestão do cuidado de enfermagem ao paciente oncológico num hospital geral: uma Teoria fundamentada nos dados. Revista de Enfermagem Referência. 2016;IV(11):61-9. http://doi.org/10.12707/ RIV16044

22. Araújo SNM, Luz MHBA, Silva GRF, Andrade EMLR, Nunes LCC, Moura RO. O paciente oncológico com mucosite oral: desafios para o cuidado de enfermagem. Rev Latino-Am Enfermagem 2015;23(2):267-74. https://doi.org/10.1590/0104-1169.0090.2551

23. Silva FS, Silva GS, Costa ACM, Filha FSSC, Júnior FCM, Câmara JT. Cuidados de enfermagem a pacientes oncológicos: revisão integrativa. Res Soc Dev. 2019;8(6):e35861037. http://doi.org/10.33448/rsd-v8i6.1037

24. Santos ACL, Leite NL, Gomes ET, Cabral MFCT, Cavalcanti ATA, Vieira JCM. Elaboration of a hospital protocol for nursing care to patients with intestinal stomata. Rev Enferm UFPI. 2019;8(4):34-40. https://doi.org/10.26694/2238-7234.8434-40 